\title{
ANTI DIARRHEA EFFECT OF ETHANOL EXTRACT KECAPI BARK (SANDORICUM KOETJAPE MERR) ON MALE GUINEA PIG INDUCED WITH CASTOR OIL AND BACTERIA ESCHERICHIA COLI
}

\author{
EVA DIANSARI*, EDY SUWARSO, AMINAH DALIMUNTHE
}

Department of Pharmacology, Faculty of Pharmacy, Universitas Sumatera Utara, Medan, Indonesia. Email: ephalg8@gmail.com Received: 12 October 2017, Revised: 07 February 2018 and Accepted: 14 February 2018

\begin{abstract}
Objective: Kecapi bark (Sandoricum koetjape Merr.) is a plant of the Meliaceae family that is often used by people to treat diarrhea and abdominal pain. This study aims to determine the effects of antidiarrheal from the ethanol extract of the Kecapi stem bark on induced with castor oil and bacteria Escherichia coli.

Methods: Before the in vivo on male guinea pig test was switched first, then $10 \mathrm{ml}$ of castor oil was induced and $7.7 \mathrm{ml}$ of $E$. coli male guinea pig was induced, then each male guinea was given a variation of dose ethanol extract kecapi stem bark and loperamide as the comparison. Parameters
\end{abstract} measured in this study were the start time of diarrhea, consistency of feces, frequency, and duration of diarrhea.

Result: The results obtained showed that ethanol extract of kecapi bark antidiarrheal effect on guinea pigs induced castor oil (dose of 800 mg/kg body weight) and E. coli.

Conclusion: Ethanol extract of Kecapi bark has an activity of antidiarrheal.

Keywords: Kecapi bark extracts, Castor oil, Escherichia coli, Antidiarrheal.

(C) 2018 The Authors. Published by Innovare Academic Sciences Pvt Ltd. This is an open access article under the CC BY license (http://creativecommons. org/licenses/by/4. 0/) DOI: http://dx.doi.org/10.22159/ajpcr.2018.v11s1.26571

\section{INTRODUCTION}

Indonesia is one of the potential drug-producing countries with its biodiversity. Biodiversity Indonesia ranks third largest in the world after Brazil and Zaire. When viewed from the diversity of flora, quite a lot of plant species that can be utilized as a medicinal plant [1].

Diarrhea is a condition in which there is an increased frequency of defecation and decreased consistency of the outflow compared with normal intestinal tract normal.

Diarrhea can also be chronic and sometimes cause severe complications when not treated properly. If diarrhea is only several times a day and stops within 1-2 days, this does not need special handling. If there is defecation 8-15 times a day, accompanied by abdominal pain, fluid, and many feces, then need to be wary. The danger are the loss of body fluids and salt, especially sodium and potassium, if it happens for day. Elderly and infant, very sensitive and easy to dehydration and, not infrequently in going to death [2].

Causes of diarrhea are various, among others, the presence of viral infections (Rotavirus and Adenovirus), bacterial infections (Shigella, Salmonella, and Escherichia coli), carbohydrate malabsorption (lactose intolerance), stale food, toxic, or food allergies [2].

Inside the small intestine, the castor oil is hydrolyzed by the lipase enzyme into glycerol and Risenosolate acid. This risenosolate acid is the active ingredient as a laxative. As a laxative of this drug is not much used again because many drugs are safer. Castor oil causes dehydration with electrolyte disturbance. Eschericia coli and oleum ricini are induction in experimental research. Oleum ricini (castor oil) is used as a stimulant for the occurrence of diarrhea. This antidiarrheal study is devoted to nonspecific diarrhea such as diarrhea due to faulty eating (food is too spicy, thus speeding the peristaltic intestines), gastrointestinal and intestinal disability in lactose metabolism (found in animal milk) called lactose intolerance, inability to metabolize certain fruits, or vegetables (cabbage, mustard, jackfruit, and durian) [3].
Kecapi bark Sandoricum koetjape has potential that can be used as a medicine for diseases caused by bacteria and fungi and is used as a traditional medicine for whitish and antipyretic [4].

From some of the literature results have not been studied by other chemical compounds of kecapi bark $[5,6]$.

Based on the research that has been done on the efficacy of natural materials, further research is needed to determine the effectiveness and content of $S$. koetjape Merr. as an alternative herbal remedy, so it is expected to anticipate the spread of diarrheal diseases.

\section{METHODS}

\section{Plant materials}

The materials used in the manufacture of the extract are kecapi bark obtained from the north sumatra guinea pig (300-400 g), aquades and $80 \%$ technical ethanol. 1\% CMC, lopamid ${ }^{\circledR}$ tablets, Escherecia coli bacteria, and castor oil.

The tools used in the manufacture of extracts are analytical scales, blenders, spatulas, rotary evaporators, measuring cups, beaker glass, funnels, filter paper, aluminum foil,pans, electric cookers, and thermometers. The tools used in the analysis are analytical scales, watch cups, measuring pipes, measuring cups, measuring flasks, suction balls, fine filter paper, spectrophotometers, vortex, vacuum ovens, desiccators, test tubes, centrifuges, electric stoves, filter paper, rat, and syringe scale $5 \mathrm{ml}$ (One med).

\section{Experimental animals}

The research method is divided into 2 stages. The first stage using Oleum ricini inducer was in vivo study using Completely Randomized Design (RAL) with 1 factor consisting of 6 groups, each group had 5 guinea pig. Group 1 (negative control) of normal marmots did not experience diarrhea, Group 2 (positive control) diarrhea without treatment, Group 3 (drug control) diarrhea with loperamide drug treatment, Group 4 diarrhea with treatment dose $400 \mathrm{mg} / \mathrm{kg}$ body weight, Group 5 diarrhea with treatment dose $800 \mathrm{mg} / \mathrm{kg}$ body weight, and Group 6 diarrhea with dose treatment $1600 \mathrm{mg} / \mathrm{kg}$ body weight. 
The second stage used inducer E. coli induction, in vivo study using Completely Randomized Design (RAL) with 1 factor consisting of 6 Groups, each group had 4 mice. Group 1 (negative control) normal mice did not have diarrhea, Group 2 (positive control) diarrhea without treatment, Group 3 (drug control) diarrhea with treatment of drug loperamide, Group 4 diarrhea with treatment dose $400 \mathrm{mg} / \mathrm{kg} \mathrm{bb}$, Group 5 diarrhea with treatment dose $800 \mathrm{mg} / \mathrm{kg}$ body weight, and Group 6 diarrhea with dose treatment $1600 \mathrm{mg} / \mathrm{kg}$ body weight.

\section{Preparation of plant extract}

About $300 \mathrm{~g}$ of Simplicia particle moistened with $150 \mathrm{ml}$ of the part solvent, inserted into a closed vessel for at least $3 \mathrm{~h}$. Move the mass gradually into the percolator while each pressed carefully, then poured with enough liquid until the liquid begins dripping and above the crude Simplicia there is a layer of solvent, percolator closed, left for $24 \mathrm{~h}$. Then opened the valve percolator, allowed liquid to drip at a speed of one ml per minute, repeatedly added liquid so that there is always a one $\mathrm{cm}$ of a layer above the simplicia [7]. Percolation was stopped, if the last $500 \mathrm{mg}$ of refined pouring was evaporated, leaving no residual. The obtained granulation was concentrated with a low-pressure vacuum evaporator at a temperature not exceeding $50^{\circ} \mathrm{C}$ until a viscous extract was obtained. Then, dried with Freeze dryer for $\pm 24 \mathrm{~h}$ and extract obtained as much as $82.92 \mathrm{~g}$.

\section{In vivo antidiarrheal activity}

In vivo research that guinea pig was adapted for 1 week. The guinea pigs are fasted for 12 hours before the study, then grouped into 6 groups of 5 guinea pig each. All guinea pigs are given Oleum ricini at different doses according to weight, except for negative controls. 30 min after administration of Oleum ricini, each group was treated, i.e., Group 1 was administered Oleum ricini with different dose according to body weight and CMC $1 \%$ as a negative control. Group 3 was administered Oleum ricini and loperamide $\mathrm{HCl}$ each corresponding to the body weight of guinea pig as a drug control. Groups 4,5 , and 6 were given doses of 1 , 2, and 3 of $400 \mathrm{mg} / \mathrm{kg} \mathrm{bw}, 800 \mathrm{mg} / \mathrm{kg} \mathrm{bw}$, and $1600 \mathrm{mg} / \mathrm{kg}$ body weight each according to the body weight of guinea pig, all treatments administered orally.

The second stage of in vivo research is that guinea pig is adapted for 1 week. The guinea pig is fasted for $12 \mathrm{~h}$ before the study, then grouped into 6 groups of each 4 guinea pig. All guinea pigs are given $E$. coli bacteria with different doses according to weight, except for negative controls. 30 min after administration of $E$. coli bacteria, each group was treated, i.e., Group 1 was given E. coli bacteria with different dose according to body weight and CMC $1 \%$ as a negative control. Group 3 was given $E$. coli and loperamide $\mathrm{HCl}$ bacteria each corresponding to the body weight of guinea pig as a drug control. Groups 4, 5, and 6 were given doses of 1,2 , and 3 of $400 \mathrm{mg} / \mathrm{kg} \mathrm{bw}, 800 \mathrm{mg} / \mathrm{kg}$ bw, and $1600 \mathrm{mg} / \mathrm{kg}$ body weight each according to the body weight of guinea pig, all treatments administered orally.

\section{Data analysis}

Antidiarrheal test data were analyzed using one-way ANOVA SPSS.

\section{RESULTS AND DISCUSSION}

\section{Characteristics of raw materials}

Determination of water content of simplicia kecapi bark is 5,98\% have fulfilled standardization in general that is not more than $10 \%$. [8]. Excess water in the Simplicia will cause the growth of microbes, fungi, or insects, and encourage damage to the active ingredients contained therein because it can decompose (hydrolysis) [9].

The result of characterization of Simplicia bark of kecapi stalk obtained by water-soluble sari level $15.35 \%$ and ethanol soluble content of $14.82 \%$. The purpose of the determination content is to determine the content of extracts of dissolved materials in water solvents and ethanol [10].

The results of total ash level determination on kecapi bark Simplicia were $6.42 \%$, and acid soluble ash content was $1.56 \%$. The determination of ash content is a method of measuring the level of ash being heated to a certain temperature, because the organic compounds and their derivatives will be destructed and evaporate so that only minerals and inorganic elements remain, and this shows the internal and external minerals contained in a Simplicia [10]. Table 1 for table characterization simplicia.

\section{Testing of antidiarrheal effect in vivo}

In vivo observation begins by looking at the onset of diarrhea by looking at the consistency of mucus/sugary mucus fecal feces. Each group induced castor oil and E. coli bacteria. The result of the determination of the beginning of diarrhea, the average value of each treatment group, is for the induction group castor oil from the comparison group to the variation of the extract dose obtained time $352.2 \mathrm{~min}$ for the occurrence of diarrhea, in the E. coli bacterial inducing group. The time obtained from the occurrence of diarrhea to the normal feces for the castor oil induction group to the variation of the extract dose was obtained at $1335.2 \mathrm{~min}$, and so on bacterial inducer. Tables 2-4 are table time of occurrence of diarrhea.

The result of the determination of the consistency of the feces is done by looking at the shape of the feces that occur, can be categorized into three groups, namely, the slimy or aqueous consistency with a large water absorption diameter of $1.5 \mathrm{~cm}$, the consistency of softening with a water absorption diameter between $1 \mathrm{~cm}$ and $1.5 \mathrm{~cm}$ and consistency normal with a small water absorption diameter of $1 \mathrm{~cm}$, in addition to observing the water absorption diameter of the formed feces, also observed the time of occurrence and the weight of the feces formed [11]. From the result of the determination of consistency of feces on castor oil induced all group having liquid phase and on

Table 1: Result of characterization of simplicia powder of kecapi bark

\begin{tabular}{ll}
\hline Parameter & Result (\%) \\
\hline Water content & 5.98 \\
Water-soluble extract & 15.35 \\
Ethanol soluble content of & 14.82 \\
Total ash content OF & 6.42 \\
Ash acid unsolvable rate & 1.56 \\
\hline
\end{tabular}

Table 2: Time of diarrhea

\begin{tabular}{|c|c|c|}
\hline \multirow[t]{2}{*}{ Treatment } & \multicolumn{2}{|c|}{ Time when diarrhea occurs (min) } \\
\hline & Inducer bacteria & Inducer castor oil \\
\hline $\mathrm{CMC} \mathrm{Na}$ & $338 \pm 17.88$ & $369 \pm 12.45$ \\
\hline Loperamide & $334 \pm 31.30$ & $363 \pm 15.62$ \\
\hline $\begin{array}{l}\text { Dose } 400 \mathrm{mg} / \mathrm{kg} \text { body } \\
\text { weight }\end{array}$ & $338 \pm 22.80$ & $363 \pm 17.88$ \\
\hline $\begin{array}{l}\text { Dose } 800 \mathrm{mg} / \mathrm{kg} \text { body } \\
\text { weight }\end{array}$ & $340 \pm 30.82$ & $378 \pm 12.55$ \\
\hline $\begin{array}{l}\text { Dose } 1600 \mathrm{mg} / \mathrm{kg} \text { body } \\
\text { weight }\end{array}$ & $328 \pm 22.80$ & $374 \pm 14.74$ \\
\hline
\end{tabular}

Table 3: Time table occurred to normal phase

\begin{tabular}{lll}
\hline Treatment & \multicolumn{2}{l}{$\begin{array}{l}\text { Time when starting into normal } \\
\text { phase (min) }\end{array}$} \\
\cline { 2 - 3 } & Inducer bacteria & Inducer castor oil \\
\hline Cmc Na & $1337.6 \pm 16.211$ & $\left.1335.2 \pm 14.856^{*}\right)$ \\
$\begin{array}{l}\text { Loperamide } \\
\text { Dose } 400 \mathrm{mg} / \mathrm{kg} \text { body } \\
\text { weight }\end{array}$ & $1115.4 \pm 39.093$ & $\left.1129.0 \pm 46.422^{* *}\right)$ \\
$\begin{array}{l}\text { Dose } 800 \mathrm{mg} / \mathrm{kg} \text { body } \\
\text { weight }\end{array}$ & $1115.2 \pm 32.958$ & $1123.4 \pm 29.917$ \\
$\begin{array}{l}\text { Dose } 1600 \mathrm{mg} / \mathrm{kg} \text { body } \\
\text { weight }\end{array}$ & $1104.0 \pm 44.238$ & $\left.1115.8 \pm 30.720^{* *}\right)$ \\
\hline
\end{tabular}

*) Distinctively different between control and treatment $(\mathrm{p}<0.05)$, ${ }^{* *}$ ) were not significantly different in each treatment $(p>0.05)$ 
consistency of feces after given normal feces comparison, in giving of ethanol extract of kecapi bark at dose $400 \mathrm{mg} / \mathrm{kg}$ body weight hence obtained normal feces still inconsistency liquid, dose $800 \mathrm{mg} / \mathrm{kg}$ body weight then obtained normal feces still in soft consistency and dose $1600 \mathrm{mg} / \mathrm{kg}$ body weight then obtained normal feces where the consistency of fesesnya normal so is the result of consistency of feces on $E$. coli bacteria inducer. In the application of ethanol extract of kecapi bark with dose of $400 \mathrm{mg} / \mathrm{kg}$ body weight, the normal feces are still in liquid consistency, dose $800 \mathrm{mg} / \mathrm{kg}$ body weight, so the normal feces are still in soft consistency and dose $1600 \mathrm{mg} / \mathrm{kg}$ body weight obtained normal feces where consistency of feces normal. The weight ratio of diarrhea feces of both inducers in Table 4 shows the comparison of normal feces weight of both inducers in Table 4 .

From the results of stool consistency determination on castor oil inducer and E. coli bacteria, all groups experienced liquid stool at the beginning of diarrhea and on consistency of feses normal (solid) after treatment was given. The statistical analysis on the normal (solid) feces weight of both inducers gave insignificant value in the two-way ANOVA test (Conditions induction of $E$. coli and castor oil were equal/ p $>0.05$ ). Two-way ANOVA test to the treatment obtained significant results $(p<0.05)$. Looking at the above two-way ANOVA test results on the mean difference test between treatments with Duncan induced effect was the same, the Duncan test was performed by combining the two inducer data for the test average difference with Duncan test. Results obtained from each inducer which have result as strong as the loperamide suspension is at dosage of ethanol extract of harp bark of $800 \mathrm{mg} / \mathrm{kg}$ body weight and $1600 \mathrm{~g} / \mathrm{kg}$ body weight. This is because the number of different doses affects the strength to suppress the diarrhea, the higher the dose given, the greater the antidiarrheal effect produced by the dose of the drug. According to supandiman et al.,1997 to reduce the frequency of diarrhea is often used spasmolitik drugs, but this is not recommended in diarrhea due to infection of germs. Table 5 comparison of the normal feces weight of the two inducers.

The higher the concentration, the smaller the development of bacteria, which means the less number of bacteria that can survive. This shows

Table 4: Comparison of weight diarrhea feces in both inducers

\begin{tabular}{lll}
\hline \multirow{2}{*}{ Treatment } & \multicolumn{2}{c}{ Weight feces diarrhea (g) } \\
\cline { 2 - 3 } & Inducer bacteria & Inducer castor oil \\
\hline $\mathrm{Cmc} \mathrm{Na}$ & $0.8638 \pm 0.048$ & $0.8816 \pm 0.059$ \\
$\begin{array}{l}\text { Loperamide } \\
\text { Dose } 400 \mathrm{mg} / \mathrm{kg} \text { body } \\
\text { weight }\end{array}$ & $0.8478 \pm 0.054$ & $0.8480 \pm 0.055$ \\
$\begin{array}{l}\text { Dose } 800 \mathrm{mg} / \mathrm{kg} \text { body } \\
\text { weight }\end{array}$ & $0.8444 \pm 0.032$ & $0.8224 \pm 0.087$ \\
$\begin{array}{l}\text { Dose } 1600 \mathrm{mg} / \mathrm{kg} \text { body } \\
\text { weight }\end{array}$ & $0.8942 \pm 0.069$ & $0.8744 \pm 0.047$ \\
\hline
\end{tabular}

Table 5: Comparison of the normal feces weight of the two inducers

\begin{tabular}{|c|c|c|}
\hline \multirow[t]{2}{*}{ Treatment } & \multicolumn{2}{|c|}{ Normal face weight (g) } \\
\hline & Inducer bacteria & Inducer castor oil \\
\hline $\mathrm{Cmc} \mathrm{Na}$ & $0.8832 \pm 0.044$ & $0.8841 \pm 0.041 *\}$ \\
\hline Loperamide & $0.2946 \pm 0.033$ & $\left.0.2848 \pm 0.035^{* *}\right)$ \\
\hline $\begin{array}{l}\text { Dose } 400 \mathrm{mg} / \mathrm{kg} \text { body } \\
\text { weight }\end{array}$ & $0.653 \pm 0.089$ & $0.6736 \pm 0.061$ \\
\hline $\begin{array}{l}\text { Dose } 800 \mathrm{mg} / \mathrm{kg} \text { body } \\
\text { weight }\end{array}$ & $0.4058 \pm 0.116$ & $\left.0.438 \pm 0.091^{* *}\right)$ \\
\hline $\begin{array}{l}\text { Dose } 1600 \mathrm{mg} / \mathrm{kg} \text { body } \\
\text { weight }\end{array}$ & $0.3004 \pm 0.014$ & $\left.0.312 \pm 0.027^{* *}\right)$ \\
\hline
\end{tabular}

that with increasing concentration the greater the level of active ingredients that function as antibacterial so that the ability in it inhibits the growth of smaller bacteria [12].

The ability of an antimicrobial agent to eliminate microorganisms' life depends on the concentration of the antimicrobial agent [13]. This means that antimicrobial ingredients in a germ environment determine the life of germs exposed. In addition to concentration factors, the type of antimicrobial ingredients also determines the ability to inhibit the growth of germs. In this study the presence of chemical compound showed antibacterial properties [14].

Alkaloids are heterocyclic nitrogen compounds, known to have antimicrobial activity. In vivo according to Karou et al., alkaloid compounds can inhibit the growth of Gram-positive and Gramnegative bacteria, but the mechanism of inhibition of alkaloids on bacteria is unclear [14]. According to research Wink, et al. (1998), ajmaline, berbamine, boldin, cynconine, emetine, harmaline, harmine, lobeline, norharman, quinidine, quinine, and sanguinarine belonging to alkaloids inhibit DNA polymerase [15]. The compounds that inhibit DNA polymerase will also be able to inhibit protein biosynthesis in the translation process. Harborne added that alkaloids can disrupt the formation of peptidoglycan components in bacterial cells, causing the loss of cell wall function as an osmotic pressure protecto [5]. This causes the bacterial cell to become sensitive to osmotic pressure, the high osmotic pressure in the bacterial cell will cause lysis of the bacterial cell [16].

To cause loss of function of cell membrane as osmotic pressure. This causes the bacterial cell to become sensitive to osmotic pressure, the high osmotic pressure in the bacterial cell will cause lysis of the bacterial cell of the compound to inactivate bacterial adhesion or bacterial attachment to the host, inactivate essential enzymes, transport cell membrane proteins, and the seizure of minerals required by bacteria [17-19]. Disabling of bacterial adhesins causes inhibition or decrease of bacterial attachment to host cells, resulting in a decrease in pathogenicity of bacteria. Disabling of enzymes in bacteria occurs because of the formation of complex compounds between tannins with enzymes or enzyme substrates, it results in inactive enzymes $[18,20]$, whereas according to Scalbert deprivation or mineral deprivation occurs with the formation of covalent bonds between a functional group of tannins with essential minerals required by bacteria, thereby causing the bacterial cell metabolism to interfere with the reduction of essential minerals [18]. According to Harborne, phenolic compounds are important compounds because they are large classes between plant compounds [5]. The antimicrobial mechanism of phenolic compounds in vivo is by interfering with the work of bacterial cytoplasmic membranes, including interfering with active transport and proton strength [3].

\section{CONFLICTS OF INTERESTS}

We declare that there is no conflict of interest.

\section{AUTHORS CONTRIBUTION}

All authors equally contributed.

\section{REFERENCES}

1. Hernani. Temulawak (Curcuma xanthorrhiza Roxb) Indonesian Medicinal Plants. Use and Usefulness. Jakarta: Popular Torch Library; 2004.

2. Mansjoer A, Wardhani WI, Setiowulan W, Suprohaita. Stadium Generale Medicine. Issue 3, Print II, Jakarta: Media Aesculapius; 2000.

3. dan Gilman G. Basic Pharmacology Therapeutics. In: Hardman JG, Limbird LE, editors. Consultant Alfred Goodman Gilman, Interpretation of ITB School of Physical Interpretation Team. 10 $0^{\text {th }}$ ed., Vol. 1. Jakarta: EGC; 2007.

4. Dira S, Yenni C. Identification of Antibacterial Compounds on Leaves (Sandoricum koetjape (Burm.f.)). J Chem 2009;3:61-8.

5. Harborne JB. Phytochemical Methods. Bandung: Bandung ITB Publisher; 1996. 
6. Verheij, EW, dan Coronel RE. Southeast Asia Resources 2. Prosea., Jakarta: PT. Gramedia Pustaka Utama; 1997.

7. Ditjen PO. Indonesian Pharmacopoeia. $3^{\text {rd }}$ ed. Jakarta: Ministry of Health Republic of Indonesia; 1979.

8. Ditjen PO. Indonesian Pharmacopoeia. $4^{\text {th }}$ ed. Jakarta: Ministry of Health Republic of Indonesia; 1995.

9. WHO. Quality Control Methods for Medicinal Plant Material. Switzerland; WHO; 1998.

10. Depkes RI. Common Standard Parameters of Medicinal Plant Extracts. First Print. Jakarta: Ministry of Health RI; 2000.

11. Enda WG. Test Effect of Antidiarrhea of Bark Shell Salam (Syzygium polyanthum (Wight) Walp) Ethanol Extract against Male Mice. Thesis University of Sumatera Utara; 2009.

12. Ajizah A. Sensitivity of Salmonella thyphimurium against the leaf extract of Psidiium Guajava L. Bioscientiae 2004;1:31-8.

13. Schlegel, G. General Microbiology. $7^{\text {th }}$ ed. England: Cambridge University Press; 1993

14. Karou D. Antibacterial activity of alkaloids from Sida acuta. Afr J Biotechnol 2006;5:195-200.
15. Wink M, Schmeler T, Latz-Bruning B. Modes of action of allelochemical alcaloids: Interaction with neuroreceptors, DNA and other molecular targets. Journal Chem Ecol 1998;24(11):1881-936.

16. Dhiah N, Sugiyarto G, Ari S. Activity antibacterial extract desearch Carica pubescens from dieng plateau the bacteria cause diarrheal disease. J Pasca UNS 2013;1:1-12.

17. Bell TA, John L, Smart WW. Pectinase and cellulose enzyme inhibitor from sericea and certain other plants. Bot Gaz 1965;126:40-45.

18. Supandiman I. Phytopharmaca testing clinic containing psidiifolium extractum, curcuma domestica rhizoma extractum and attapulgite on non-specific acute diarrhea Sufferers. Majalah Kedokt Indones 1997;47:157-61.

19. Min BR, Barry TN, Attwood GT, McNabb WC. The effect of condensed tannins on the nutrition and health of ruminants fed fresh temperate forages: A review. Anim Feed Sci Technol 2003;106:3-19.

20. Brunton LL, Robinson J, dan Stevenson DE. A note on the toxicity and solvent properties of dimethyl sulphoxide. J Pharm Pharmacol $1963 ; 15: 688-92$ 